\title{
Synthesis, Spectroscopic Characterization, and Biological Evaluation Studies of 5-Bromo-3-(((hydroxy-2-methylquinolin-7-yl)methylene) hydrazono)indolin-2-one and Its Metal (II) Complexes
}

\author{
Kuruba Siddappa and Nabiya Sultana Mayana \\ Department of Studies and Research in Chemistry, Gulbarga University, Gulbarga, Karnataka 585106, India \\ Correspondence should be addressed to Kuruba Siddappa; siddappa_65@rediffmail.com
}

Received 21 May 2014; Revised 12 September 2014; Accepted 15 September 2014; Published 12 October 2014

Academic Editor: Viktor Brabec

Copyright (C) 2014 K. Siddappa and N. S. Mayana. This is an open access article distributed under the Creative Commons Attribution License, which permits unrestricted use, distribution, and reproduction in any medium, provided the original work is properly cited.

\begin{abstract}
The Schiff base ligand 5-bromo-3-(((8-hydroxy-2-methylquinolin-7-yl)methylene)hydrazono)indolin-2-one (BHMQMHI) was prepared via condensation of 5-bromo-3-hydrazonoindolin-2-one and 7-formyl-8-hydroxy-2-methylquinoline and its Co(II), $\mathrm{Ni}(\mathrm{II}), \mathrm{Cu}(\mathrm{II}), \mathrm{Zn}(\mathrm{II}), \mathrm{Cd}(\mathrm{II})$, and $\mathrm{Hg}(\mathrm{II})$ complexes have been synthesized and characterized by elemental analysis, conductance data, magnetic susceptibility measurements, IR, UV-Vis, mass spectrometry, ${ }^{1} \mathrm{H}$ NMR, ESR, XRD, and thermal studies. By these spectral studies it is found that $\mathrm{Co}(\mathrm{II}), \mathrm{Ni}(\mathrm{II})$, and $\mathrm{Cu}(\mathrm{II})$ complexes have exhibited octahedral geometry whereas the $\mathrm{Zn}$ (II), $\mathrm{Cd}(\mathrm{II})$, and $\mathrm{Hg}(\mathrm{II})$ complexes have exhibited tetrahedral geometry. Potentiometric studies have been carried out on complexes of Schiff base (BHMQMHI) with $\mathrm{Cu}(\mathrm{II}), \mathrm{Co}(\mathrm{II})$, and $\mathrm{Ni}(\mathrm{II})$. Calvin-Bjerrum $\mathrm{pH}$-titration technique as used by Irving and Rossotti has been applied to determine stability constants in mixed solvents at $25 \pm 1^{\circ} \mathrm{C}$. The present study reports the protonation constants of this ligand and stability constants of its metal complexes in dioxane-water $(50 \%$, v/v) mixtures. Metal-ligand stability constants fall in the order of $\mathrm{Cu}(\mathrm{II})>\mathrm{Co}(\mathrm{II})>\mathrm{Ni}(\mathrm{II})$ which is in agreement with those reported by Irving stability order. The Schiff base (BHMQMHI) and its metal complexes have been screened for their in vitro antibacterial and antifungal activities by minimum inhibitory concentration (MIC) method. The DNA cleavage activities of all the complexes were studied by agarose gel electrophoresis method. In addition, the free ligand along with its complexes has been studied for their antioxidant activity.
\end{abstract}

\section{Introduction}

Schiff base complexes have undergone a phenomenal growth during the recent years because of the versatility offered by these complexes in the field of industries, catalysis and biological system, and so forth. In this way, the synthesis, structural investigation, and reaction of transition metal Schiff bases have received a special attention, because of their biological activities as antitumoral, antifungal, and antiviral activities [1].

Hydrazones possessing an azomethine proton $(-\mathrm{NHN}=$ $\mathrm{CH}-$ ) constitute an important class of compounds for new drug development. Many researchers have synthesised these compounds as well as their metal complexes as target structures and evaluated their biological activities. These observations have guided the development of new hydrazones with varied biological activities. The biological activity of complexes derived from hydrazones has been studied and contrasted with regard to their antibacterial, antitumoral, antiviral, antimalarial, and antitubercular properties. It has also been shown that the azomethine $\mathrm{N}$, which has a lone pair of electrons in an $s p^{2}$ hybridised orbital, is biologically important [2]. The isatin molecule $(1 \mathrm{H}$ indole-2, 3-Dione) is a versatile moiety that displays diverse biological activities. In this paper, we report the synthesis, structural characterization, thermal decomposition, and 
TABLE 1: The experimental procedure involves the acid titration, ligand titration, and metal titration. $T=25 \pm 1^{\circ} \mathrm{C} 50 \%$ Dioxanewater $\mu=0.1 \mathrm{M} / 0.2 \mathrm{M} \mathrm{NaClO}_{4}$.

\begin{tabular}{lccc}
\hline $\begin{array}{l}\text { Solution } \\
\text { (initial concentration) }\end{array}$ & $\begin{array}{c}\text { Acid } \\
\text { titration }\end{array}$ & $\begin{array}{c}\text { Ligand } \\
\text { titration }\end{array}$ & $\begin{array}{c}\text { Metal } \\
\text { titration }\end{array}$ \\
\hline $\mathrm{HClO}_{4}(0.01 \mathrm{M})$ & $5.0 \mathrm{~mL}$ & $5.0 \mathrm{~mL}$ & $5.0 \mathrm{~mL}$ \\
$\mathrm{NaClO}_{4}(1 \mathrm{M} / 2 \mathrm{M})$ & $5.0 \mathrm{~mL}$ & $5.0 \mathrm{~mL}$ & $5.0 \mathrm{~mL}$ \\
Dioxane & $25.0 \mathrm{~mL}$ & $25.0 \mathrm{~mL}$ & $25.0 \mathrm{~mL}$ \\
Water & $15.0 \mathrm{~mL}$ & $10.0 \mathrm{~mL}$ & $5.0 \mathrm{~mL}$ \\
Ligand $(0.01 \mathrm{M})$ & - & $5.0 \mathrm{~mL}$ & $5.0 \mathrm{~mL}$ \\
Metal $(0.01 \mathrm{M})$ & - & - & $5.0 \mathrm{~mL}$ \\
\hline
\end{tabular}

biological studies of some transition metal complexes with the host of a bishydrazone derived from 5-bromo-3hydrazonoindolin-2-one and 7-formyl-8-hydroxy-2-methylquinoline, namely, (5-bromo-3-(((8-hydroxy-2-methylquinolin-7-yl)methylene)hydrazono)indolin-2-one

(BHMQMHI)).

\section{Experimental}

2.1. Materials and Reagents. All chemicals used were of analytical grade. 5-Bromo isatin and hydrazine hydrate (99\%) were obtained from Fluka and Sisco chemicals.

2.2. Solutions. Dioxane was purified by the standard procedures [3]. Ligand solution was prepared in double distilled alcohol. Metal salt solutions were prepared by dissolving the corresponding metal salt in double distilled deionized water and standardized by standard volumetric methods [3].

Calvin-Bjerrum Technique. The experimental procedure involves the acid titration, ligand titration, and metal titration. The details of titrations are shown in Table 1 . The total volume in all the cases was $50 \mathrm{~mL}$.

2.3. Physical Measurements. pH measurements were carried out using Elico pH-meter model L1-122. Elemental analysis was carried out using a Heracus Carlo Erba $1108 \mathrm{CHN}$ analyzer at STIC, Cochin. The IR spectra of the Schiff base (BHMQMHI) and its $\mathrm{Co}(\mathrm{II}), \mathrm{Ni}(\mathrm{II}), \mathrm{Cu}(\mathrm{II}), \mathrm{Zn}(\mathrm{II})$, $\mathrm{Cd}(\mathrm{II})$, and $\mathrm{Hg}(\mathrm{II})$ complexes were recorded in the region of $4000-250 \mathrm{~cm}^{-1}$ on a Perkin Elmer Spectrum RX-IFTIR spectrophotometer. The electronic spectra of the Co(II), $\mathrm{Ni}(\mathrm{II})$, and $\mathrm{Cu}(\mathrm{II})$ complexes were recorded on an ELICO SL164 double beam UV-visible spectrophotometer in the range of 200-1200 $\mathrm{nm}$ in DMF $\left(10^{-3} \mathrm{M}\right)$ solution. Magnetic susceptibility measurements were made at room temperature on a Gouy balance using $\mathrm{Hg}\left[\mathrm{Co}(\mathrm{NCS})_{4}\right]$ as the calibrant. Molar conductivity measurements were recorded on an ELICO CM180 conductivity bridge in DMF solution $\left(10^{-3} \mathrm{M}\right)$ using a dip-type conductivity cell fitted with a platinum electrode. The ${ }^{1} \mathrm{H}$ NMR spectra were recorded in DMSO- $\mathrm{d}_{6}$ on a Bruker
$500 \mathrm{MHz}$ spectrophotometer using TMS as an internal standard. The mass spectra were recorded on a JEOL GC mate mass spectrophotometer. The ESR spectrum of the $\mathrm{Cu}$ (II) complex in the polycrystalline state was recorded on a VarianE-4X band EPR spectrophotometer using TCNE as the " $g$ " marker $(g=2.00277)$ at room temperature. Thermal analyses were measured from room temperature to $1000^{\circ} \mathrm{C}$ in $\mathrm{N}_{2}$ on a perkin Elmer, Diamond TG/DTA model thermal analyzer at STIC, Cochin, with a heating rate of $10^{\circ} \mathrm{C} \mathrm{min}^{-1}$. The XRD patterns of the $\mathrm{Cu}(\mathrm{II})$ complex were recorded on a Bruker AXS D8 Advance X-ray diffractometer using $\mathrm{Cu} \mathrm{K} \alpha=1.5404$ radiation $(\lambda \AA)$.

\subsection{Procedures}

2.4.1. Potentiometric Measurements. The potentiometric measurements were carried out at $25 \pm 1^{\circ} \mathrm{C}$ and at constant ionic strengths $(0.1 \mathrm{M}$ and $0.2 \mathrm{M})$. The $\mathrm{pH}$-meter was calibrated before each titration using standard buffers. The ionization constants of the investigated Schiff base (BHMQMHI) and the stability constants of its metal complexes with $\mathrm{Co}(\mathrm{II}), \mathrm{Ni}(\mathrm{II})$, and $\mathrm{Cu}(\mathrm{II})$ ions were determined potentiometrically using the technique of Calvin-Bjerrum Technique. The ionization constants of the ligand are calculated using the equation used by Irving and Rossotti while metal-ligand stability constants were calculated using methods applied for computing successive stability constants.

2.4.2. Synthesis of Schiff Base Ligand. 5-Bromo-3-(((8-hydroxy-2-methylquinolin-7-yl)methylene)hydrazono)indolin-2-one (BHMQMHI): the Schiff base has been synthesized by refluxing the equimolar mixture of hot methanolic solution of 7-formyl-8-hydroxy-2-methylquinoline $(0.01 \mathrm{~mol}, 30 \mathrm{~mL})$ and hot methanolic solution of 5-bromo-3-hydrazonoindolin-2-one $(0.01 \mathrm{~mol}, 30 \mathrm{~mL})$ for $6-7 \mathrm{~h}$ in presence of catalytical amount of hydrochloric acid. The product obtained after the evaporation of the solvent was filtered, washed with cold methanol, and finally recrystallized from methanol to afford Schiff base (BHMQMHI) as shown in Figure 1 . The purity of the compound has been checked by thin layer chromatography (TLC).

2.4.3. Synthesis of Metal Complexes. The metal complexes were prepared using metal chlorides and the Schiff base (BHMQMHI) by the general method. An ethanolic solution (40 mL) of Schiff base and $\mathrm{Co}(\mathrm{II}), \mathrm{Ni}(\mathrm{II})$, and $\mathrm{Cu}(\mathrm{II})$ chlorides in 1:2 molar ratio and 1:1 molar ratio for $\mathrm{Zn}(\mathrm{II}), \mathrm{Cd}(\mathrm{II})$, and $\mathrm{Hg}(\mathrm{II})$ complexes were refluxed on water bath for about $4 \mathrm{~h}$. An aqueous solution of sodium acetate was added to the reaction mixture to adjust the $\mathrm{pH}$ to 6.0-7.0 and reflux was further continued for about an hour. The separated solid complexes were filtered off and washed thoroughly with water and then with little warm ethanol. The complexes obtained were finally dried under vacuum desiccator over fused $\mathrm{CaCl}_{2}$. Elemental analysis data are shown in Table 2 . The complexes were analyzed for their metal and chloride contents by standard methods [3]. 
<smiles>C=C1Nc2ccc(Br)cc2/C1=N/N</smiles>

5-Bromo-3-hydrazonoindolin-2-one<smiles>Cc1ccc2ccc(C=O)c(O)c2n1</smiles>

7-Formyl-8-hydroxy-2-methylquinoline $\mathrm{MeOH}$
$\mathrm{HCl}$
Reflux: 6-7 hr<smiles>Cc1ccc2ccc(/C=N/N=C3\C(=O)Nc4ccc(Br)cc43)c(O)c2n1</smiles>

5-Bromo-3-(((8-hydroxy-2-methylquinoline-7-yl)methylene)hydrazono)indolin-2-one

FIGURE 1: Schematic representation of Schiff base (BHMQMHI).

TABLE 2: Physical and analytical data of the ligand (BHMQMHI) and its metal (II) complexes.

\begin{tabular}{|c|c|c|c|c|c|c|c|c|c|}
\hline \multirow{2}{*}{ Compound } & \multirow{2}{*}{ Molecular formula } & \multirow{2}{*}{ Yield (\%) } & \multicolumn{5}{|c|}{ Found (calculated) \% } & \multirow{2}{*}{$\begin{array}{c}\Omega \mathrm{m} \\
\left(\Omega^{-1} \mathrm{~cm}^{2} \mathrm{~mol}^{-1}\right)\end{array}$} & \multirow{2}{*}{$\begin{array}{c}\mu_{\mathrm{eff}} \\
(\mathrm{BM})\end{array}$} \\
\hline & & & $\mathrm{C}$ & $\mathrm{H}$ & $\mathrm{N}$ & M & $\mathrm{Cl}$ & & \\
\hline Ligand & {$\left[\mathrm{C}_{19} \mathrm{H}_{13} \mathrm{~N}_{4} \mathrm{O}_{2} \mathrm{Br}\right]$} & 81 & $55.76(55.54)$ & $3.20(3.16)$ & $13.69(13.53)$ & - & - & - & - \\
\hline $\begin{array}{l}\mathrm{Co}(\mathrm{II}) \\
\text { complex }\end{array}$ & {$\left[\mathrm{Co}\left(\mathrm{C}_{38} \mathrm{H}_{24} \mathrm{~N}_{8} \mathrm{O}_{4} \mathrm{Br}_{2}\right)\right]$} & 79 & $52.14(52.01)$ & $2.76(2.68)$ & $12.80(12.78)$ & $6.73(6.68)$ & - & 27.23 & 4.88 \\
\hline $\begin{array}{l}\mathrm{Ni}(\mathrm{II}) \\
\text { complex }\end{array}$ & {$\left[\mathrm{Ni}\left(\mathrm{C}_{38} \mathrm{H}_{24} \mathrm{~N}_{8} \mathrm{O}_{4} \mathrm{Br}_{2}\right)\right]$} & 70 & $52.15(52.08)$ & $2.76(2.63)$ & $12.80(12.76)$ & $6.70(6.63)$ & - & 20.43 & 3.00 \\
\hline $\begin{array}{l}\mathrm{Cu}(\mathrm{II}) \\
\text { complex }\end{array}$ & {$\left[\mathrm{Cu}\left(\mathrm{C}_{38} \mathrm{H}_{24} \mathrm{~N}_{8} \mathrm{O}_{4} \mathrm{Br}_{2}\right)\right]$} & 65 & $51.86(51.78)$ & $2.75(2.68)$ & $12.73(12.63)$ & $7.22(7.12)$ & - & 18.45 & 1.94 \\
\hline $\begin{array}{l}\mathrm{Zn}(\mathrm{II}) \\
\text { complex }\end{array}$ & {$\left[\mathrm{Zn}\left(\mathrm{C}_{19} \mathrm{H}_{12} \mathrm{~N}_{4} \mathrm{O}_{2} \mathrm{Br}\right) \mathrm{Cl}\right]$} & 80 & $44.83(44.77)$ & $2.38(2.28)$ & $11.01(10.08)$ & $12.84(12.70)$ & $6.96(6.76)$ & 22.81 & - \\
\hline $\begin{array}{l}\text { Cd(II) } \\
\text { complex }\end{array}$ & {$\left[\mathrm{Cd}\left(\mathrm{C}_{19} \mathrm{H}_{12} \mathrm{~N}_{4} \mathrm{O}_{2} \mathrm{Br}\right) \mathrm{Cl}\right]$} & 77 & $41.04(39.93)$ & $2.18(2.00)$ & $10.08(9.93)$ & $20.21(20.19)$ & $6.37(6.26)$ & 23.76 & - \\
\hline $\begin{array}{l}\mathrm{Hg}(\mathrm{II}) \\
\text { complex }\end{array}$ & {$\left[\mathrm{Hg}\left(\mathrm{C}_{19} \mathrm{H}_{12} \mathrm{~N}_{4} \mathrm{O}_{2} \mathrm{Br}\right) \mathrm{Cl}\right]$} & 66 & $35.42(34.54)$ & $1.88(1.78)$ & $8.70(8.65)$ & - & - & 29.76 & - \\
\hline
\end{tabular}

\section{Pharmacology}

3.1. Antibacterial and Antifungal Activities. Antibacterial and antifungal activity of ligand and their complexes has been determined by serial tube dilution technique [4]. The stock solution of each compound was prepared by dissolving $10 \mathrm{mg}$ of each test compound in $10 \mathrm{~mL}$ of freshly distilled DMSO. The various concentrations of the test compounds $(100,75$, 50,25 , and $12.5 \mu \mathrm{g} / \mathrm{mL}^{-1}$ ) were prepared by diluting the stock solution with the required volume of freshly distilled DMSO.
The MIC was measured after $24 \mathrm{~h}$ in case of antibacterial activity and $48 \mathrm{~h}$ for antifungal activity.

The in vitro biological screening effects of the investigated compounds were tested against the bacteria $S$. aureus, $B$. subtilis, and $P$. aeruginosa cultured on Mueller Hinton agar media. The antifungal activity of the Schiff base and its metal complexes was tested against A. flavus, A. niger, and $C$. albicans on Czapek-Dox agar media. The control containing only DMSO and the standard antibiotic (Gentamycin and Amphotericin) was also kept for comparison [5]. 
TABLE 3: IR spectral bands of the ligand (BHMQMHI) and its metal complexes $\left(\mathrm{cm}^{-1}\right)$.

\begin{tabular}{|c|c|c|c|c|c|c|c|}
\hline Tentative assignments & $\mathrm{L}$ & Co(II) complex & $\mathrm{Ni}(\mathrm{II})$ complex & $\mathrm{Cu}(\mathrm{II})$ complex & $\mathrm{Zn}(\mathrm{II})$ complex & $\mathrm{Cd}(\mathrm{II})$ complex & $\mathrm{Hg}$ (II) complex \\
\hline Hydrogen bonded $\mathrm{OH}$ group & 3364 & - & - & - & - & - & - \\
\hline Indole ring $\mathrm{NH}$ & 3203 & 3203 & 3203 & 3203 & 3023 & 3203 & 3203 \\
\hline$\nu(\mathrm{C}=\mathrm{O})$ ring & 1696 & 1685 & 1686 & 1679 & 1647 & 1672 & 1667 \\
\hline$\nu(\mathrm{C}=\mathrm{N})$ ring & 1603 & 1603 & 1603 & 1603 & 1603 & 1603 & 1603 \\
\hline$\nu(\mathrm{C}=\mathrm{N})$ aldimine & 1583 & 1565 & 1525 & 1530 & 1533 & 1505 & 1549 \\
\hline$\nu(\mathrm{C}-\mathrm{O})$ & 1289 & 1300 & 1307 & 1306 & 1314 & 1344 & 1360 \\
\hline$\nu(\mathrm{N}-\mathrm{N})$ & 991 & 1067 & 1082 & 1035 & 1099 & 1059 & 1033 \\
\hline$\nu(\mathrm{M}-\mathrm{N})$ & - & 479 & 496 & 468 & 477 & 489 & 489 \\
\hline$v(\mathrm{M}-\mathrm{O})$ & - & 533 & 578 & 500 & 500 & 523 & 598 \\
\hline$v(\mathrm{M}-\mathrm{Cl})$ & - & - & - & - & 344 & 358 & 366 \\
\hline
\end{tabular}

3.2. Antioxidant Activity: Radical Scavenging Activity. The radical scavenging activity ligand (BHMQMHI) and its complexes were determined by using 1, 1-diphenyl-2, 2-picryl hydrazyl-free radical (DPPH) assay method [6]. DPPH is a stable free-radical molecule, accept an electrons or hydrogen radicals to become a stable diamagnetic molecule and also contained an odd electron in its structure that is frequently used for detection of the radical scavenging activity in chemical analysis. The reduction capability of DPPH radicals was determined by a decrease in its absorbance at $517 \mathrm{~nm}$ induced by antioxidants. The absorption maximum of a stable DPPH radical in ethanol was at $517 \mathrm{~nm}$. The absorbance decreased when the DPPH is scavenged by an antioxidant, through donation of hydrogen to form a stable DPPH molecule. In the radical form, those molecules show an absorbance at $517 \mathrm{~nm}$, which disappeared after acceptance of an electron or hydrogen radical from an antioxidant compound to become a stable diamagnetic spin-paired molecule. The stock solutions $(1 \mathrm{mg} / \mathrm{mL})$ of the ligand and its complexes were diluted to a final concentration of $25,50,75$, and $100 \mu \mathrm{g} / \mathrm{mL}$ in methanol. DPPH solution $(1 \mathrm{~mL}, 0.1 \mathrm{mmol})$ was added to $2.5 \mathrm{~mL}$ of test solution of different concentration and allowed to react at room temperature. After $30 \mathrm{~min}$ the absorbance was measured at $517 \mathrm{~nm}$. A graph was plotted with percentage scavenging effects on the $y$-axis and concentration $(\mu \mathrm{g} / \mathrm{mL})$ on the $x$-axis. Radical scavenging activity was expressed as a percentage and was calculated using the following formula:

$$
\text { Scavenging effect }(\%)=\frac{\text { Control OD }- \text { Sample OD }}{\text { Control OD }} \times 100 \text {. }
$$

The scavenging capability of the ligand and its complexes were compared with standard drugs, namely, butylated hydroxyl anisole (BHA) and tertiary butylated hydroxyl quinoline (TBHQ) and ascorbic acid.

3.3. DNA Cleavage Experiment. Preparation of culture media and DNA isolation of Calf-thymus were done according to the literature procedure [7]. Nutrient broth $\left(10 \mathrm{~g} \mathrm{~L}^{-1}\right.$ of peptone, $5 \mathrm{~g} \mathrm{~L}^{-1}$ of yeast extract and $10 \mathrm{gL}^{-1}$ of $\mathrm{NaCl}$ ) was used for culturing of Calf-thymus.
The cleavage of Calf-thymus DNA was determined by agarose gel electrophoresis [5]. Calf-thymus DNA was cultured, isolated, and used as DNA for the experiment. The precipitated DNA was separated by centrifugation and the pellet was dried and dissolved in tris buffer $(10 \mathrm{mM}$ tris $\mathrm{pH}$ 8.0) and stored in cold condition. $25 \mu \mathrm{g}$ of the test samples was added to the isolated Calf-thymus DNA and incubated for $2 \mathrm{~h}$ at $37^{\circ} \mathrm{C}$. After incubation, the samples were electrophoresed for $45 \mathrm{~min}$ at $50 \mathrm{~V}$ on agarose gel using TAE buffer ( $4.84 \mathrm{~g}$ tris base, $\mathrm{pH}$ 8.0, 0.5 M EDTA/L). After the run, gel was removed and stained with $10 \mu \mathrm{g} / \mathrm{mL}$ ethidium bromide (ETBR) for 10$15 \mathrm{~min}$ and the image was taken in UV transilluminator and photographed to determine the extent of DNA cleavage. The results are compared with standard DNA marker [8-10].

\section{Results and Discussion}

The Schiff base ligand and its transition metal complexes have been synthesized and characterized by spectral and elemental analytical data. All the complexes are freely soluble in acetonitrile, DMF, and DMSO and insoluble in water. The analytical data (Table 2) indicates that the stoichiometry of the complexes is $1: 2$ (metal to ligand ratio) for $\mathrm{Co}$ (II), $\mathrm{Ni}(\mathrm{II}), \mathrm{Cu}(\mathrm{II})$, and 1:1 (metal to ligand ratio) for $\mathrm{Zn}$ (II), $\mathrm{Cd}(\mathrm{II})$, and $\mathrm{Hg}$ (II) complexes. The lower conductance values (18-29 $\mathrm{Ohm}^{-1} \mathrm{~cm}^{2} \mathrm{~mol}^{-1}$ ) of the complexes support their nonelectrolytic nature of the compounds $[11,12]$.

4.1. IR Spectral Studies. The prominent infrared spectral data with the tentative assignments of the Schiff base (BHMQMHI) and its $\mathrm{Co}(\mathrm{II}), \mathrm{Ni}(\mathrm{II}), \mathrm{Cu}(\mathrm{II}), \mathrm{Zn}(\mathrm{II}), \mathrm{Cd}(\mathrm{II})$, and $\mathrm{Hg}(\mathrm{II})$ complexes are presented in Table 3.

The broad peak observed at $3364 \mathrm{~cm}^{-1}$ in the IR spectra of the ligand assigned to $v(\mathrm{OH})$, which was found to have disappeared in all the complexes, thereby indicating deprotonation and formation of metal-oxygen bond [13]. This is further supported by the shifting of phenolic $v(\mathrm{C}-$ $\mathrm{O})$ towards higher frequency, indicating the coordination of the phenolate oxygen to metal ion. The $v(\mathrm{HC}=\mathrm{N})$ vibration of the ligand occurs at $1583 \mathrm{~cm}^{-1}$, which is shifted to a lower frequency in the complexes, indicating the involvement of the azomethine nitrogen in chelation with the metal ion [14]. 
TABLE 4: Electronic spectral bands and ligand field parameters of the Co(II), Ni(II), and Cu(II) complexes in DMF (10 $\left.0^{-3} \mathrm{M}\right)$ solution.

\begin{tabular}{|c|c|c|c|c|c|c|c|c|c|}
\hline \multirow{2}{*}{ Complexes } & \multicolumn{3}{|c|}{ Transitions in $\mathrm{cm}^{-1}$} & \multirow{2}{*}{$\mathrm{Dq}\left(\mathrm{cm}^{-1}\right)$} & \multirow{2}{*}{$B^{\prime}\left(\mathrm{cm}^{-1}\right)$} & \multirow{2}{*}{$\beta$} & \multirow{2}{*}{$\beta \%$} & \multirow{2}{*}{$v_{2} / v_{1}$} & \multirow{2}{*}{ LFSE (k cal) } \\
\hline & $v_{1}$ & $v_{2}$ & $v_{3}$ & & & & & & \\
\hline Co(II) complex & 7148 & 15384 & 20000 & 823 & 929 & 0.89 & 10.64 & 2.15 & 14.11 \\
\hline $\mathrm{Ni}(\mathrm{II})$ complex & 9614 & 15384 & 25000 & 961 & 769 & 0.73 & 26.02 & 1.60 & 32.96 \\
\hline $\mathrm{Cu}$ (II) complex & & $14285-173$ & & 1583 & - & - & - & - & 27.15 \\
\hline
\end{tabular}

The band corresponding to $v(\mathrm{C}=\mathrm{O})$ at $1696 \mathrm{~cm}^{-1}$ is shifted to a lower frequency, supporting the coordination of the carbonyl oxygen [15]. However vibrational characteristics of the ring $v(\mathrm{~N}-\mathrm{H})$ and $v(\mathrm{C}=\mathrm{N})$ of the ketimine moiety remain almost unaffected, indicating the nonparticipation of these groups in coordination [16]. The bands in the regions 500598 and $468-496 \mathrm{~cm}^{-1}$ are ascribed to $\nu(\mathrm{M}-\mathrm{O})$ and $\nu\left(\mathrm{M}_{-}\right.$ $\mathrm{N})$ vibrations, respectively [17]. The bands observed in the region $344-366 \mathrm{~cm}^{-1}$ are due to the formation of $\nu(\mathrm{M}-\mathrm{Cl})$ bond, which was characteristic of the involvement of chloride atom in coordination with $\mathrm{Zn}(\mathrm{II}), \mathrm{Cd}(\mathrm{II})$ and $\mathrm{Hg}$ (II) ions. But in $\mathrm{Co}(\mathrm{II}), \mathrm{Ni}(\mathrm{II})$, and $\mathrm{Cu}(\mathrm{II})$ complexes $v(\mathrm{M}-\mathrm{Cl})$ bands are absent. From the above observations, it can be concluded that the ligand binds to the metal ion in a tridentate fashion through the deprotonated phenolate oxygen, Schiff base nitrogen, and the carbonyl oxygen of the isatin moiety.

4.2. ${ }^{1} \mathrm{H}$-NMR Spectral Studies. ${ }^{1} \mathrm{H}$-NMR spectra of the ligand (BHMQMHI) and its $\mathrm{Zn}(\mathrm{II}), \mathrm{Cd}(\mathrm{II})$, and $\mathrm{Hg}$ (II) complexes were recorded in DMSO- $\mathrm{d}^{6}$ using TMS as an internal standard and the integrated intensities of the signals are well agreed with the number of protons of each type. The signal at $\delta(10.3)(\mathrm{s}, 1 \mathrm{H})$ was assigned to phenolic $-\mathrm{OH}$ in the ligand. The signal is disappear in $\mathrm{Zn}(\mathrm{II}), \mathrm{Cd}(\mathrm{II})$ and $\mathrm{Hg}(\mathrm{II})$ complexes, which indicates the involvement of phenolic oxygen atom in the coordination via deprotonation [18]. The signal at $\delta(8.4)(\mathrm{s}, 1 \mathrm{H})$ is due to the azomethine group in the ligand (BHMQMHI). These signals shifts downfield in the regions $\delta(9.1)(\mathrm{s}, 1 \mathrm{H}), \delta(8.8)(\mathrm{s}, 1 \mathrm{H})$, and $\delta(9.0)(\mathrm{s}, 1 \mathrm{H})$ in the spectra of $\mathrm{Zn}(\mathrm{II}), \mathrm{Cd}(\mathrm{II})$, and $\mathrm{Hg}(\mathrm{II})$ complexes, respectively, and confirms the coordination of " $\mathrm{N}$ " of $(-\mathrm{C}=\mathrm{N}-)$ group in bonding with the metal ions [19]. The peak that appeared at $\delta(9.7)(\mathrm{s}, 1 \mathrm{H})$ is due to the hydrogen of $-\mathrm{NH}$ in the ligand, but in case of $\mathrm{Zn}(\mathrm{II}), \mathrm{Cd}(\mathrm{II})$, and $\mathrm{Hg}(\mathrm{II})$ complexes the peak was observed at $\delta(9.7)(\mathrm{s}, 1 \mathrm{H})$, and this signal remains unaltered in the spectra of $\mathrm{Zn}(\mathrm{II}), \mathrm{Cd}(\mathrm{II})$, and $\mathrm{Hg}(\mathrm{II})$ complexes confirming the noncoordination (-NH) in bonding with metal ions [20]. In ligand seven aromatic protons have been observed in the region $\delta(6.9-7.5)(\mathrm{m}, 7 \mathrm{H})$ as a multiplet, and it is shifted downfield in the $\mathrm{Zn}(\mathrm{II}), \mathrm{Cd}(\mathrm{II})$, and $\mathrm{Hg}(\mathrm{II})$ complexes. The signals observed at $\delta(2.5)$ are due to methyl protons that remain almost unaffected in $\mathrm{Zn}(\mathrm{II})$, $\mathrm{Cd}(\mathrm{II})$, and $\mathrm{Hg}(\mathrm{II})$ complexes indicating the nonparticipation of these groups in coordination [21].

4.3. Mass Spectral Studies. The mass spectrum of the Schiff base (BHMQMHI) shows a molecular ion peak at $m / z 409.24$, which is equivalent to its molecular weight. The mass spectra of the $\mathrm{Co}(\mathrm{II}), \mathrm{Ni}(\mathrm{II}), \mathrm{Cu}(\mathrm{II}), \mathrm{Zn}(\mathrm{II}), \mathrm{Cd}(\mathrm{II})$, and $\mathrm{Hg}(\mathrm{II})$ complexes showed a molecular ion peak at $m / z 875.39,875.15$, $880.00,509.09,556.09$, and 644.27 which is the same as that of the molecular weight of the complexes. This confirms the proposed structure for the complexes.

4.4. Electronic Spectral and Magnetic Studies. The electronic spectral data of metal (II) complexes were recorded in DMF as shown in Table 4. They have been studied with the view to obtain more information on stereochemistry of the complexes and to procedure more support for the conclusion, deduced with the help of magnetic data. The Co(II) complex of the electronic absorption bands appears at 15384 and $20000 \mathrm{~cm}^{-1}$ due to ${ }^{4} \mathrm{~T}_{1 \mathrm{~g}}(\mathrm{~F}) \rightarrow{ }^{4} \mathrm{~A}_{2 \mathrm{~g}}(\mathrm{~F})\left(v_{2}\right)$ and ${ }^{4} \mathrm{~T}_{1 \mathrm{~g}}(\mathrm{~F}) \rightarrow{ }^{4} \mathrm{~T}_{2 \mathrm{~g}}(\mathrm{P})\left(\nu_{3}\right)$ transitions, respectively, in an octahedral environment [22]. The band $v_{1}$ could not be observed because of its very low intensity. However the position of the $\nu_{1}$ band has been computed $\left(7148 \mathrm{~cm}^{-1}\right)$ by the equation $v_{1}=v_{2}-10 \mathrm{Dq}$. The ligand field parameters such as $\mathrm{Dq}, B^{\prime}, \beta$, and $\beta \%$ have been calculated by using band-fitting equation given by Underhill and Billing [23]. The crystal field splitting (Dq) energy value was at $823 \mathrm{~cm}^{-1}$. These values are well within the range and also reported by most of the octahedral Co(II) complexes. Co(II) complex under present investigation process interelectronic repulsion parameter $\left(B^{\prime}\right)$ $929 \mathrm{~cm}^{-1}$. The Racah parameter is less than free ion value suggesting a considerable orbital overlap and delocalization of electrons on the metal ion. The nephelauxetic ratio $(\beta)$ for the $\mathrm{Co}(\mathrm{II})$ complex is 0.89 . This is less than one, suggesting partial covalency in the metal ligand bond. The values Dq, $\beta, \beta \%, \nu_{2} / \nu_{1}$, and LFSE suggest the octahedral geometry for $\mathrm{Co}(\mathrm{II})$ complex [24]. The Co(II) complex displays a magnetic moment value of $4.88 \mathrm{BM}$, which is within the range of 4.46$5.53 \mathrm{BM}$.

The electronic spectrum of $\mathrm{Ni}(\mathrm{II})$ complex shows two bands at 15384 and $25000 \mathrm{~cm}^{-1}$ assignable to ${ }^{3} \mathrm{~A}_{2 \mathrm{~g}}(\mathrm{~F}) \rightarrow{ }^{3} \mathrm{~T}_{1 \mathrm{~g}}$ $(\mathrm{F})\left(v_{2}\right)$ and ${ }^{3} \mathrm{~A}_{2 \mathrm{~g}}(\mathrm{~F}) \rightarrow{ }^{3} \mathrm{~T}_{1 \mathrm{~g}}(\mathrm{P})\left(\nu_{3}\right)$ transitions, respectively, in an octahedral environment [25]. The lowest band $\nu_{1}$ was not observed due to limited range of the instrument used. However, it is calculated by using equation suggested by Billing and Underhill. Racah parameter $B^{\prime}$ is less than the free ion value of $1040 \mathrm{~cm}^{-1}$ indicating the covalent character of the complex. The ratios $\nu_{2} / \nu_{1}$ and $\beta \%$ further support the octahedral geometry around the $\mathrm{Ni}(\mathrm{II})$ ion [26]. The $\mathrm{Ni}(\mathrm{II})$ complex showed the magnetic moment value of $3.00 \mathrm{BM}$, which is within the range of 2.7-3.3 BM.

The $\mathrm{Cu}(\mathrm{II})$ complex exhibits a broad asymmetric band in the region $14285-17391 \mathrm{~cm}^{-1}$. The broadness of the band may be due to dynamic Jahn-Teller distortion and is assigned to 
TABLE 5: X-ray diffraction data of $\mathrm{Cu}(\mathrm{II})$ complex.

\begin{tabular}{|c|c|c|c|c|c|c|c|c|}
\hline \multirow{2}{*}{$2 \theta$} & \multirow{2}{*}{$\theta$} & \multirow{2}{*}{$\sin \theta$} & \multirow{2}{*}{$\sin ^{2} \theta$} & \multirow{2}{*}{$h^{2}+k^{2}+l^{2}$} & \multirow{2}{*}{$h k l$} & \multicolumn{2}{|c|}{$d$ value } & \multirow{2}{*}{$a$ in $\AA$} \\
\hline & & & & & & $\mathrm{Cal}$ & Abs & \\
\hline 15.804 & 7.902 & 0.1374 & 0.0189 & 1 & 100 & 5.6030 & 5.6008 & 5.600 \\
\hline 24.445 & 12.222 & 0.2117 & 0.0448 & $2.37234(2)$ & 110 & 3.6384 & 3.6363 & 5.600 \\
\hline 26.887 & 13.444 & 0.2324 & 0.0540 & $2.85970(3)$ & 111 & 3.3132 & 3.3120 & 5.600 \\
\hline 30.581 & 15.290 & 0.2637 & 0.0695 & $3.67509(4)$ & 220 & 2.9256 & 2.9198 & 5.600 \\
\hline 35.523 & 17.761 & 0.3050 & 0.0930 & $4.92361(5)$ & 210 & 2.5251 & 2.5241 & 5.600 \\
\hline 40.680 & 20.340 & 0.3475 & 0.1208 & $6.39237(6)$ & 211 & 2.2161 & 2.2152 & 5.600 \\
\hline 42.960 & 21.480 & 0.3661 & 0.1340 & $7.09426(7)$ & - & 2.1036 & 2.1028 & 5.600 \\
\hline 49.915 & 24.957 & 0.4219 & 0.1780 & $9.41976(9)$ & 221 & 1.8255 & 1.8248 & 5.600 \\
\hline 53.767 & 26.883 & 0.4521 & 0.2044 & 10.8179 (11) & 311 & 1.7035 & 1.7028 & 5.600 \\
\hline 56.129 & 28.064 & 0.4704 & 0.2213 & $11.7106(12)$ & 222 & 1.6373 & 1.6366 & 5.600 \\
\hline 68.526 & 34.263 & 0.5629 & 0.3169 & $16.7699(17)$ & 322 & 1.3682 & 1.3676 & 5.600 \\
\hline
\end{tabular}

${ }^{2} \mathrm{~B}_{1 \mathrm{~g}} \rightarrow{ }^{2} \mathrm{~A}_{2 \mathrm{~g}}\left(\nu_{1}\right),{ }^{2} \mathrm{~B}_{1 \mathrm{~g}} \rightarrow{ }^{2} \mathrm{E}_{\mathrm{g}}\left(\nu_{2}\right)$, and ${ }^{2} \mathrm{~B}_{1 \mathrm{~g}} \rightarrow{ }^{2} \mathrm{~B}_{2 \mathrm{~g}}\left(\nu_{3}\right)$ transitions. The $\mathrm{Cu}$ (II) complexes showed magnetic moment value of $1.94 \mathrm{BM}$, which is within the range of 1.75-2.20 BM which is consistent with octahedral geometry [27].

4.5. Thermogravimetric Analysis. The Copper (II) complex is subjected to thermogravimetric analysis in dynamic air in $40-750^{\circ} \mathrm{C}$ temperature range, at a heat ingrate of $10^{\circ} \mathrm{C} / \mathrm{min}$. The complex is stable up to $200^{\circ} \mathrm{C}$ and exhibits a single stage decomposition pattern, as is evident from the TGDTA profile. The mass loss in the single stage decomposition occurred at $221.00^{\circ} \mathrm{C}$ which can be attributed to the loss of ligand moiety further leaving behind the metal oxide residue. The complex shows gradual degradation up to $709.3^{\circ} \mathrm{C}$. The single stage decomposition of the metal complex usually occurs when there is a high degree of electron delocalization along a conjugated system which leads to uniformity in bond strength [28].

4.6. ESR Spectrum of Cu(II) Complex. The ESR spectrum of the $\mathrm{Cu}(\mathrm{II})$ complex in a polycrystalline state was recorded at room temperature. The $g_{\|}$and $g_{\perp}$ values were found to be 2.405 and 2.041, respectively. The $g_{a v}$ was calculated to be 2.057. The broadening of this signal might be due to dipolar interactions, indicating lowered site symmetry suggesting that the unpaired electron resides mainly in the $d_{x 2-\mathrm{d} y 2}$ orbital [29]. The axial symmetry parameter " $G$ " was determined as $G=\left(g_{\|}-2.00277\right) /\left(g_{\perp}-2.00277\right)=4.455$, suggesting that there is no exchange interaction in the $\mathrm{Cu}(\mathrm{II})$ complex [30].

4.7. Powder X-Ray Diffraction. The Cu(II) complex has been characterized by powder XRD studies with a view to find the type of crystal system. The XRD data of $\mathrm{Cu}(\mathrm{II})$ complex is given in Table 5. There are 11 reflections $(2 \theta)$ between 15.804 and 68.526 with maxima at $2 \theta=35.523$ corresponding to the value of $d=2.525$. The interplanar spacing $(d)$ has been calculated from the positions of intense peaks using Bragg's equation $n \lambda=2 d \operatorname{Sin} \theta$ (where $\lambda=1.54056 \AA$ ). The observed and calculated values of $d$ are quite consistent. The experimental values of $\sin ^{2} \theta /$ common factor are recorded for

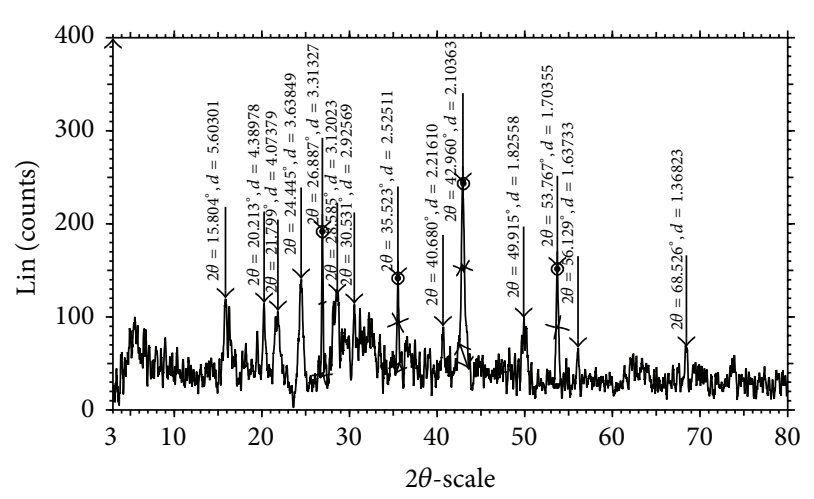

Figure 2: Powder XRD pattern of $\mathrm{Cu}(\mathrm{II})$ complex.

each peak in Figure 2. The $h^{2}+k^{2}+l^{2}$ values of the complex were found to be $1,2,3,4,5,6,7,9,11,12$, and 17 . The presence of forbidden number 7 indicates the $\mathrm{Cu}(\mathrm{II})$ complex belongs to hexagonal system [31].

4.8. Potentiometric Determination of the Ionization Constants. The ionization constants of the ionizable group in Schiff base under investigation are determined by a method similar to that described by Calvin-Bjerrum [32]. The average of protons associated with the ligand $\left(\bar{n}_{A}\right)$ at different $\mathrm{pH}$ values is calculated utilizing acid and ligand titration curves (Figures 3(a) and 3(b)). The pKa values can be calculated from the curves obtained by plotting $\bar{n}_{A}$ versus $\mathrm{pH}$. The formation curves are found between 0 and 1 . This indicates that the ligands have one dissociable proton. Ligand exhibits only one $\mathrm{pKa}$ value in the range of 10.0 in $0.1 \mathrm{M}$ ionic strength and 9.4 in $0.2 \mathrm{M}$ ionic strengths, respectively, in $50 \%$ dioxane-water, this can be attributed to the ionization of phenolic -OH of the Schiff base (BHMQMHI).

4.9. Potentiometric Determination of the Stability Constants. The stability constants of the $\mathrm{Co}(\mathrm{II}), \mathrm{Ni}(\mathrm{II})$, and $\mathrm{Cu}(\mathrm{II})$ complexes with (BHMQMHI) are determined potentiometrically using the method described by Calvin-Bjerrum. The 


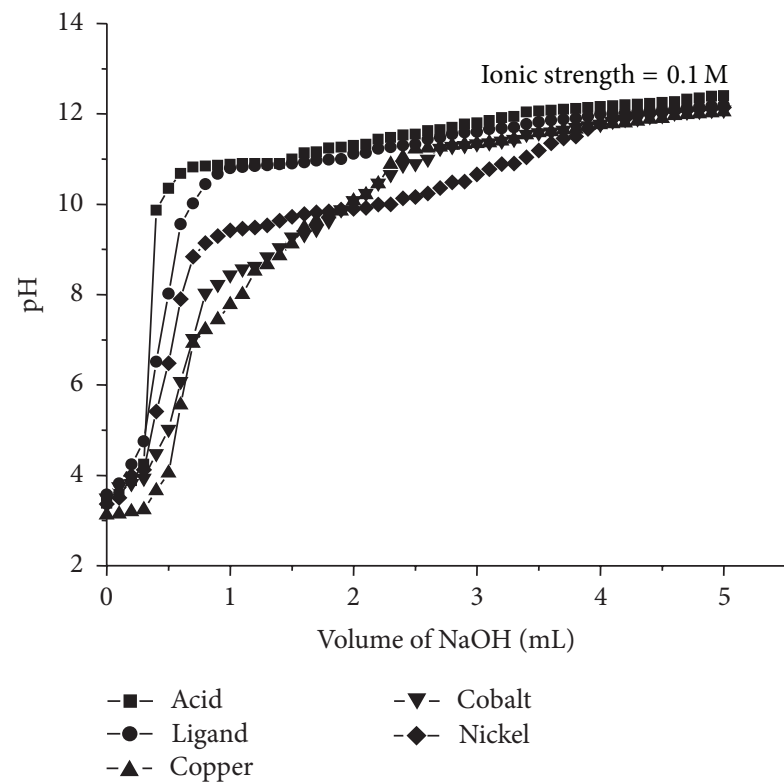

(a)

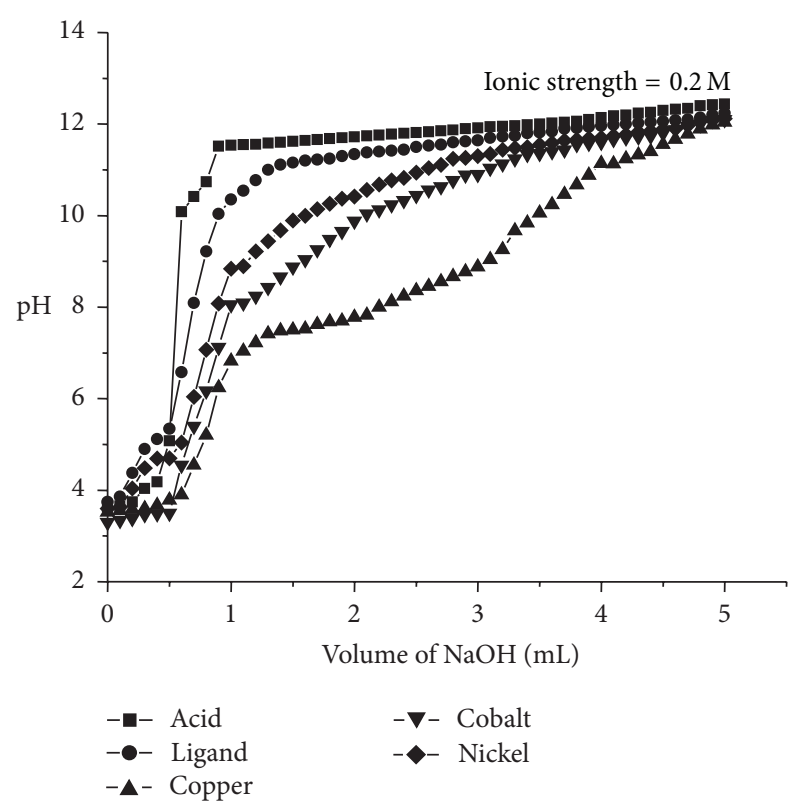

(b)

FIGURE 3: Plot of $\mathrm{pH}$ versus volume of $\mathrm{NaOH}$ added.

TABLE 6: Cumulative data of $\log k$ and $\log \beta$ values for Schiff base (BHMQMHI) complexes.

\begin{tabular}{|c|c|c|c|c|c|c|c|c|c|c|c|c|}
\hline \multirow{5}{*}{ Solvent } & \multicolumn{6}{|c|}{ Ionic strength $=0.1 \mathrm{M}$} & \multicolumn{6}{|c|}{ Ionic strength $=0.2 \mathrm{M}$} \\
\hline & \multicolumn{6}{|c|}{$\mathrm{pKa}$} & \multicolumn{6}{|c|}{$\mathrm{pKa}$} \\
\hline & \multicolumn{6}{|c|}{10.0} & \multicolumn{6}{|c|}{9.4} \\
\hline & \multicolumn{2}{|c|}{ Copper } & \multicolumn{2}{|c|}{ Cobalt } & \multicolumn{2}{|c|}{ Nickel } & \multicolumn{2}{|c|}{ Copper } & \multicolumn{2}{|c|}{ Cobalt } & \multicolumn{2}{|c|}{ Nickel } \\
\hline & $\log k$ & $\log \beta$ & $\log k$ & $\log \beta$ & $\log k$ & $\log \beta$ & $\log k$ & $\log \beta$ & $\log k$ & $\log \beta$ & $\log k$ & $\log \beta$ \\
\hline 50\% Dioxane-water & 5.644 & 3.900 & 5.554 & 5.025 & 4.5199 & 4.2300 & 5.499 & 5.0325 & 5.476 & 3.536 & 4.442 & 3.835 \\
\hline
\end{tabular}

formation curves of the investigated complexes are obtained by plotting a graph between the average number of ligands attached per metal ion $(\bar{n})$ and the free ligand exponent $(\mathrm{pL})$. Values of $\bar{n}$ and $\mathrm{pL}$ are calculated. The maximum $\bar{n}$ values calculated for metal-ligand system are found not to exceed two indicating the formation of $1: 1$ and $1: 2$ (metal: ligand) complexes. The mean $\log K$ and $\log \beta$ values of the $\mathrm{Co}(\mathrm{II})$, $\mathrm{Ni}(\mathrm{II})$, and $\mathrm{Cu}(\mathrm{II})$ complexes with Schiff base (BHMQMHI) are listed in Table 6 . The order of stability constants is found to be $\mathrm{Cu}(\mathrm{II})>\mathrm{Co}$ (II) $>\mathrm{Ni}$ (II) in accordance with the Irving and Williams order [33] for divalent metal ions of the $3 \mathrm{~d}$ series. It is clear from Table 6 that the stability of $\mathrm{Cu}$ (II) complexes is considerably larger as compared to other metals of the $3 \mathrm{~d}$ series. Under the influence of the ligand field, $\mathrm{Cu}(\mathrm{II})\left(3 d^{9}\right)$ will receive some extra stabilization [34] due to tetragonal distortion of octahedral symmetry in their complexes. The $\mathrm{Cu}$ (II) complexes will be further stabilized due to the Jahn-Teller effect [35].

\section{Pharmacology Results}

5.1. Antimicrobial Evaluation of Ligand (BHMQMHI) and Its Metal (II) Complexes. The ligand and metal complexes were screened for antibacterial activity and the results are presented in Table 7. The synthesized Schiff base (BHMQMHI) has an inhibitory effect (MIC values of $75-100 \mu \mathrm{g} / \mathrm{mL}^{-1}$ ) on growth of the tested bacterial strains. All complexes showed greater bactericidal activities against $S$. aureus (MIC $12.5-50 \mu \mathrm{g} / \mathrm{mL}^{-1}$ ), B. subtilis (MIC $12.5-50 \mu \mathrm{g} / \mathrm{mL}^{-1}$ ), and $P$. aeruginosa (MIC $12.5-50 \mu \mathrm{g} / \mathrm{mL}^{-1}$ ) than the ligand. In the fungal studies, the ligand had an inhibitory effect (MIC values in range $50-100 \mu \mathrm{g} / \mathrm{mL}^{-1}$ ) on the growth of the tested strains and complexes again showed greater fungicidal activities against $A$. flavus (MIC $12.5-75 \mu \mathrm{g} / \mathrm{mL}^{-1}$ ), A. niger (MIC $12.5-25 \mu \mathrm{g} / \mathrm{mL}^{-1}$ ), and C. albicans (MIC $12.5-50 \mu \mathrm{g} / \mathrm{mL}^{-1}$ ). $\mathrm{Co}(\mathrm{II})$ and $\mathrm{Zn}$ (II) complexes had greater bacterial and fungal activities than the ligand (BHMQMHI).

All the metal complexes individually exhibited varying degrees of inhibitory effect on the growth of the tested bacterial/fungal species. Table 7 shows the activity of the metal complexes became more pronounced when coordinated with the metal ions [36]. This enhancement in the activity may be due to the structure of Schiff base ligand by possessing an azomethine $(\mathrm{C}=\mathrm{N})$ linkage. The toxic activity of the complexes with the ligand can be ascribed to the increase in the lipophilic nature of the complexes arising 
TABLE 7: The antimicrobial activity of ligand and its metal (II) complexes evaluated by MIC $\left(\mu \mathrm{g} / \mathrm{mL}^{-1}\right)$.

\begin{tabular}{|c|c|c|c|c|c|c|}
\hline Schiff base/complexes & S. aureus & B. subtilis & P. aeruginosa & A. flavus & A. niger & C. albicans \\
\hline Ligand & 100 & 75 & 75 & 100 & 50 & 75 \\
\hline Co(II) complex & 12.50 & 12.50 & 12.50 & 12.50 & 12.50 & 12.50 \\
\hline $\mathrm{Ni}(\mathrm{II})$ complex & 12.50 & 25 & 25 & 25 & 25 & 12.50 \\
\hline $\mathrm{Cu}$ (II) complex & 25 & 50 & 12.50 & 75 & 12.50 & 25 \\
\hline $\mathrm{Zn}(\mathrm{II})$ complex & 12.50 & 12.50 & 12.50 & 12.50 & 12.50 & 12.50 \\
\hline Cd(II) complex & 50 & 50 & 25 & 50 & 25 & 50 \\
\hline Hg(II) complex & 25 & 12.50 & 50 & 12.50 & 25 & 12.50 \\
\hline Gentamycine & 12.50 & 12.50 & 12.50 & - & - & - \\
\hline Amphotericin & - & - & - & 12.50 & 12.50 & 12.50 \\
\hline
\end{tabular}

from chelation. The mode of action of complexes involves the formation of hydrogen bonds with the imino group by the active sites leading to interference with the cell wall synthesis. This hydrogen bond formation damages the cytoplasmic membrane and the cell permeability may also be altered leading to cell death [37].

A comparative study of the ligand and complexes (MIC values) indicated that the complexes exhibited higher antimicrobial activity than the free ligand. Such increased activity of the complexes can be explained on the basis of Overtone's concept and Tweedy's chelation theory [38]. These complexes also disturb the respiration process of the cell and thus block the synthesis of the proteins, restricting the further growth of the organism. Furthermore, the mode of action of the compound may involve the formation of a hydrogen bond through the azomethine group with the active center of the cell, resulting in interference with the normal cell processes. In general, metal complexes are more active than ligands because metal complexes may serve as a vehicle for the activation of ligands as the principle cytotoxic species [39].

5.2. Antioxidant Activity: Radical Scavenging Activity. The metal (II) complexes prepared from Schiff base (BHMQMHI) were subjected for free radical scavenging activity by DPPH method $[5,6]$. From the investigation it was clearly observed that metal complexes scavenge DPPH effectively than Schiff base (BHMQMHI). The Co(II), Zn(II), Cu(II), and $\mathrm{Ni}(\mathrm{II})$ complexes show superior activity while $\mathrm{Cd}(\mathrm{II})$ and $\mathrm{Hg}$ (II) complexes are moderate activity as a radical scavenger compound with standards as shown in Figure 4.

5.3. DNA Cleavage Efficiency. The Schiff base metal complexes were subjected to their DNA cleavage activity by agarose gel electrophoresis method [5]. From Figure 5, it was clearly indicated that the Co(II) (lane M1), Ni(II) (lane M2), $\mathrm{Cu}(\mathrm{II})$ (lane M3), Zn(II) (lane M4), and Cd(II) (lane M5) shows complete DNA cleavage activity and $\mathrm{Hg}$ (II) (lane M6) complex shows partial DNA cleavage activity. The Schiff base metal complexes have acted on DNA effectively, since as there was molecular weight difference between the control and the treated DNA samples. The completion of gel electrophoresis experiment clearly indicated that the intensity of the treated DNA samples has diminished due to the cleavage of DNA. These results indicated that the metal ions played an

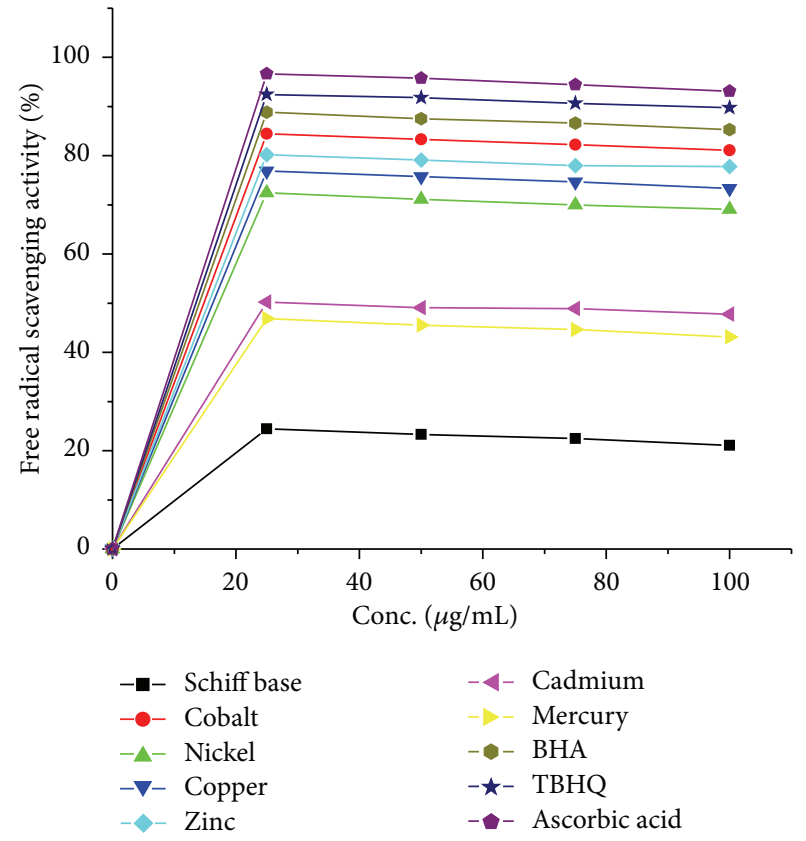

Figure 4: Antioxidant results of Schiff base and its metal (II) complexes.

important role in the cleavage of DNA [40]. The information obtained in this study could be helpful in the understanding of the mechanism of interactions of metal (II) complexes with nucleic acids and should be useful in the development of potential probes for investigation of the structure and conformation of DNA or new therapeutic agents for some diseases [41].

\section{Conclusion}

This study shows that synthesized Schiff base (BHMQMHI) acts as tridentate ligand coordinating to metal ion through azomethine nitrogen, carbonyl oxygen, and phenolic oxygen atom via deprotonation. The synthesized new Schiff base and its metal complexes have been confirmed by the analytical data, IR, electronic, mass spectrometry, ${ }^{1} \mathrm{H}$ NMR, ESR spectral data, magnetic susceptibility, molar conductance, XRD, and thermal studies. The results of the potentiometric 


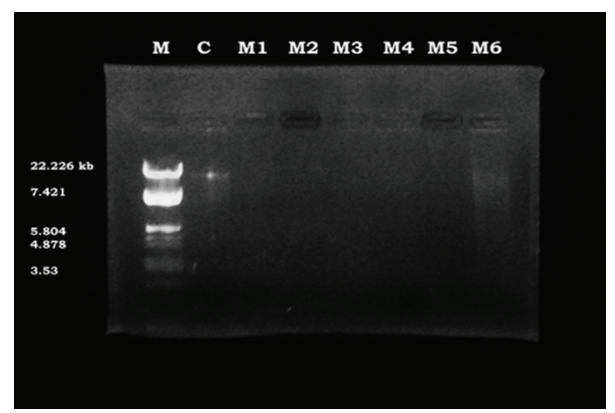

FIGURE 5: Gel picture showing the cleavage analysis of samples.

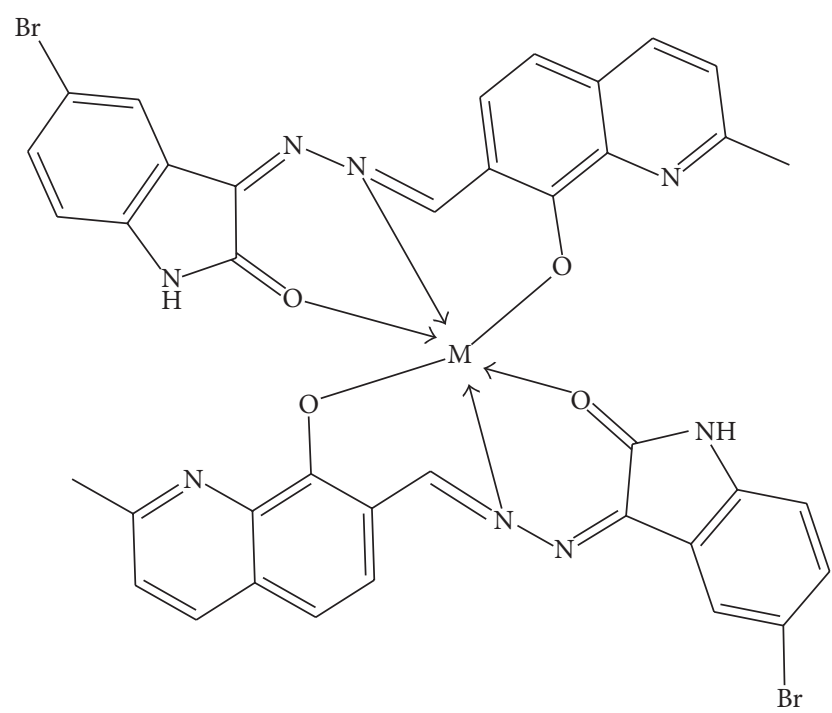

Figure 6: Proposed structure of $\mathrm{Co}(\mathrm{II}), \mathrm{Ni}(\mathrm{II})$, and $\mathrm{Cu}$ (II) metal complexes (octahedral).

studies on complexes of Schiff base (BHMQMHI) with $\mathrm{Cu}(\mathrm{II}), \mathrm{Co}(\mathrm{II})$, and $\mathrm{Ni}(\mathrm{II})$ using Calvin-Bjerrum $\mathrm{pH}$-titration technique as used by Irving and Rossotti indicate that the order of stability is $\mathrm{Cu}(\mathrm{II})>\mathrm{Co}(\mathrm{II})>\mathrm{Ni}(\mathrm{II})$. This order is in accordance with Irving-Williams order of stability and formation constants $\log K$ and $\log \beta$ values are decreases as the ionic strength increases. This observation is in agreement with Debye-Hukel equation. The synthesized Schiff base metal complexes show better antibacterial and antifungal activity than the ligand. The $\mathrm{Co}(\mathrm{II}), \mathrm{Ni}(\mathrm{II}), \mathrm{Cu}(\mathrm{II}), \mathrm{Zn}(\mathrm{II})$, $\mathrm{Cd}(\mathrm{II})$, and $\mathrm{Hg}(\mathrm{II})$ complexes were also found to show significant antioxidant and DNA cleavage activity. Based on the analytical and spectral studies, we propose octahedral geometry for the $\mathrm{Co}(\mathrm{II}), \mathrm{Ni}(\mathrm{II})$, and $\mathrm{Cu}(\mathrm{II})$ complexes and tetrahedral geometry for the $\mathrm{Zn}(\mathrm{II}), \mathrm{Cd}(\mathrm{II})$, and $\mathrm{Hg}(\mathrm{II})$ complexes. (Figures 6 and 7).

\section{Conflict of Interests}

The authors declare that there is no conflict of interests regarding the publication of this paper.

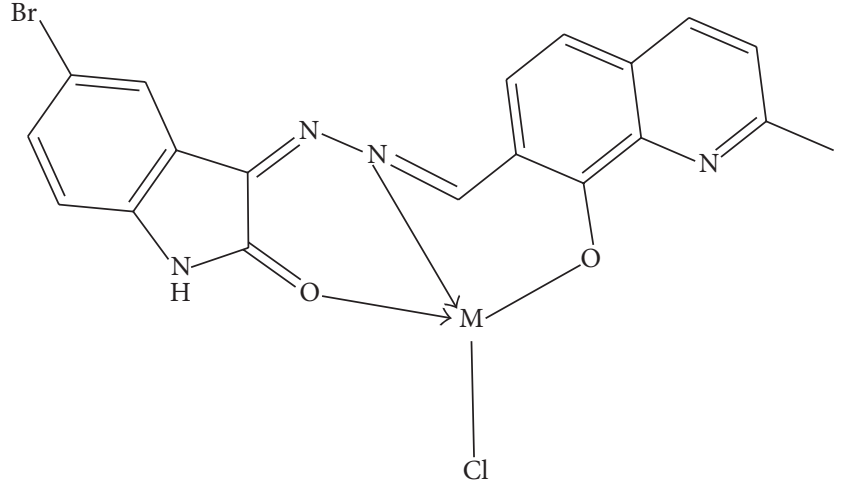

Figure 7: Proposed structure of $\mathrm{Zn}(\mathrm{II}), \mathrm{Cd}(\mathrm{II})$, and $\mathrm{Hg}(\mathrm{II})$ metal complexes (tetrahedral).

\section{Acknowledgments}

The authors are thankful to the Chairman, Department of Chemistry, Gulbarga University, Gulbarga, for encouragement and facilities. One of the authors (Nabiya Sultana Mayana) is thankful to UGC New Delhi for the grant of research fellowship in science for minority students under MANF Scheme. They are also thankful to IIT Chennai, IIT Bombay, and STIC Cochin for providing spectral data.

\section{References}

[1] R. K. Mohapatra, U. K. Mishra, S. K. Mishra, A. Mahapatra, and D. C. Dash, "Synthesis and characterization of transition metal complexes with benzimidazolyl-2-hydrazones of oanisaldehyde and furfural," Journal of the Korean Chemical Society, vol. 55, no. 6, pp. 926-931, 2011.

[2] B. Ilknur, C. E. Poyrazoglu, and B. Halil, "Synthesis, characterisation and antimicrobial activities of vic-dioxime derivatives containing heteroaromatic hydrazone groups and their metal complexes," Maejo International Journal of Science and Technology, vol. 7, no. 1, pp. 26-41, 2013.

[3] A. I. Vogel, A Text Book of Quantitative Inorganic Analysis, Longman ELBS, London, UK, 3rd edition, 1968.

[4] K. S. Prasad, L. S. Kumar, S. C. Shekar, M. Prasad, and H. D. Revanasiddappa, "Oxovanadium complexes with bidentate N, O ligands: synthesis, characterization, DNA binding, nuclease activity and antimicrobial studies," Chemical Sciences Journal, vol. 12, pp. 1-10, 2011.

[5] M. B. Halli, R. B. Sumathi, and M. Kinni, "Synthesis, spectroscopic characterization and biological evaluation studies of Schiff's base derived from naphthofuran-2-carbohydrazide with 8-formyl-7-hydroxy-4-methyl coumarin and its metal complexes," Spectrochimica Acta Part A: Molecular and Biomolecular Spectroscopy, vol. 99, pp. 46-56, 2012.

[6] K. Siddappa and S. B. Mane, "Pharmacological activity of (E) 3-2-(1-(1-hydroxynaphthalen-2-yl)methyleneamino)phenyl)-2 -methylquinazoline-4(3H)-one Schiff base and its transition metal complexes," International Journal of Pharmacy and Pharmaceutical Sciences, vol. 5, no. 3, pp. 725-732, 2013.

[7] J. Sambrook, E. F. Fritsch, and T. Miniatis, Molecular Cloning, A Laboratory Manual, Cold Spring Harbor Laboratory Press, Cold Spring Harbor, NY, USA, 2nd edition, 1989. 
[8] P. Jogi, M. Padmaja, K. V. T. S. Pavan Kumar, and C. Gyanakumari, "Studies on DNA cleavage and antimicrobial screening of transition metal complexes of a schiff base rived from 2(aminomethyl)-benzimidazole and p-chloro benzalhy," Journal of Chemical and Pharmaceutical Research, vol. 4, no. 2, pp. 13891397, 2012.

[9] P. Kavitha, M. Rama Chary, B. V. V. A. Singavarapu, and K. Laxma Reddy, "Synthesis, characterization, biological activity and DNA cleavage studies of tridentate Schiff bases and their Co(II) complexes," Journal of Saudi Chemical Society, 2013.

[10] B. Manjula and S. Arul antony, "Studies on DNA cleavage and antimicrobial screening of transition metal complexes of 4-aminoantipyrine Schiff base," Research Journal of Chemical Sciences, vol. 3, no. 12, pp. 22-28, 2013.

[11] W. J. Geary, "The use of conductivity measurements in organic solvents for the characterisation of coordination compounds," Coordination Chemistry Reviews, vol. 7, no. 1, pp. 81-122, 1971.

[12] E. Akila, M. Usharani, P. Maheswaran, and R. Rajavel, "Spectral, magnetic, biocidal screening and DNA cleavage studies of binuclear metal (II) complexes of tetracoordinate Schiff base ligand of 3, 3/-dihydroxybenzidine," International Journal of Recent Scientific Research, vol. 4, no. 10, pp. 1497-1503, 2013.

[13] B. Lakshmi, K. N. Shivananda, G. A. Prakash, A. M. Isloor, and K. N. Mahendra, "Synthesis and characterization of schiff base metal complexes and reactivity studies with malemide epoxy resin," The Bulletin of the Korean Chemical Society, vol. 33, no. 2, pp. 473-482, 2012.

[14] K. Siddappa, S. B. Mane, and D. Manikprabhu, "Spectral characterization and 3D molecular modeling studies of metal complexes involving the $\mathrm{O}, \mathrm{N}$-donor environment of quinazoline$4(3 \mathrm{H})$-one Schiff base and their biological studies," The Scientific World Journal, vol. 2014, Article ID 817365, 13 pages, 2014.

[15] A. N. Al-Shareefi, S. H. Kadhim, and W. A. Jawad, "Synthesis and study of $\mathrm{Fe}(\mathrm{III}), \mathrm{Co}(\mathrm{II}), \mathrm{Ni}(\mathrm{II})$ and $\mathrm{Cu}(\mathrm{II})$ complexes of new Schiff's base ligand derived from 4-amino antipyrine," Journal of Applicable Chemistry, vol. 2, no. 3, pp. 438-446, 2013.

[16] R. K. Mohapatra, M. Dash, S. B. Patjoshia, and D. C. Dash, "Synthesis and spectral characterization of transition metal complexes with benzothiazolyl-2-hydrazones of salicylidene acetone and salicylidene acetophenone," Acta Chimica \& Pharmaceutica Indica, vol. 2, no. 4, pp. 156-162, 2012.

[17] S. S. Sawant, V. Pawar, S. Janrao, R. S. Yamgar, and Y. Nivid, "Synthesis and characterization of transition metal complexes of novel Schiff base 8-[(z)-[3-(n-methylamino)propyl] iminomethyl]-7-hydroxy-4-methyl-2h-chromen-2-one][nmapimhmc] and their biological activities," International Journal of Research in Pharmacy and Chemistry, vol. 3, no. 3, pp. 636-644, 2013.

[18] S. R. Kelode and P. R. Mandlik, "Synthesis, characterization, thermal and antibacterial studies of cobalt (II), nickel (II), copper (II), and zinc (II) complexes of hydrazone Schiff base," International Journal of Chemical and Pharmaceutical Sciences, vol. 3, no. 3, pp. 30-33, 2012.

[19] B. Anupama and C. Gyana Kumari, "Cobalt (II) complexes of ONO donor Schiff bases and N, N donor ligands: synthesis, characterization, antimicrobial and DNA binding study," International Journal of Research in Chemistry and Environment, vol. 3, no. 2, pp. 172-180, 2013.

[20] Y. K. Gupta, S. C. Agarwal, S. P. Madnawat, and R. Narain, "Synthesis, characterization and antimicrobial studies of some transition metal complexes of Schiff bases," Research Journal of Chemical Sciences, vol. 2, no. 4, pp. 68-71, 2012.
[21] K. Siddappa and K. Mallikarjun, "Synthesis, characterization and antimicrobial studies of $n^{\prime}-(1-$ (5-bromo-2hydroxyphenyl)ethylidene)-2-oxo-2hchromene-3-

carbohydrazide and its metal complexes," Journal of Chemical, Biological and Physical Sciences, vol. 3, no. 4, pp. 2401-2411, 2013.

[22] K. Siddappa, K. Mallikarjun, T. Reddy, M. Mallikarjun, C. V. Reddy, and M. Tambe, "Synthesis, characterization and antimicrobial studies of $\mathrm{N}^{1}$-[(1E)-1-(2-hydroxyphenyl) ethylidene]-2oxo-2H-chromene-3-carbohydrazide and its metal complexes," E-Journal of Chemistry, vol. 6, no. 3, pp. 615-624, 2009.

[23] A. E. Underhill and D. E. Billing, "Calculations of the racah parameter B for nickel (II) and cobalt (II) compounds," Nature, vol. 210, no. 5038, pp. 834-835, 1966.

[24] K. Siddappa and K. Mallikarjun, "Synthesis, characterization and antimicrobial studies of N1-(1-(2-Hydroxy-5methylphenyl)ethylidene)-2-oxo-2H-Chromene-3-

carbohydrazide and its metal complexes," Journal of Applicable Chemistry, vol. 2, no. 3, pp. 405-414, 2013.

[25] K. Siddappa, M. Kote, P. C. Reddy, and T. Reddy, "Synthesis, Physico-Chemical and Antimicrobial Studies of N1/,N6/bis((2-hydroxyquinolin-3-yl)methylene)adipohydrazide and their metal (II) complexes," Journal of Chemical and Pharmaceutical Research, vol. 3, no. 6, pp. 780-788, 2011.

[26] K. Siddappa, B. M. Sunilkumar, and D. Manikprabhu, “(E)32-(1-(2,4-dihydroxyphenyl)ethyldeneamino)phenyl)-2-methylquinazoline- $4(3 \mathrm{H})$-one Schiff base and its metal complexes: a new drug of choice against methicillin-resistant Staphylococcus aureus," Bioinorganic Chemistry and Applications, pp. 1-8, 2013.

[27] K. Siddappa and P. Chandrakantreddy, "Synthesis, spectral and antimicrobial studies of some transition metal (II) complexes with Schiff base 3-[(2-hydroxy-6-methoxy quinolin-3-yl methylene)-amino]-2-methyl-3H-quinazoline-4-one," International Journal of Applied biology and Pharmaceutical Technology, vol. 3, no. 3, pp. 168-177, 2012.

[28] S. Prasad, P. Jayaseelan, and R. Rajavel, "Synthesis, spectral, DNA cleavage and antimicrobial studies of homo trinuclear $\mathrm{Cu}$ (II), Ni (II) and Mn (II) complexes," International Journal of Chemical Sciences, vol. 9, no. 4, pp. 1711-1724, 2011.

[29] M. Usharani, E. Akila, and R. Rajavel, "Derivation of N, $\mathrm{N}$, O donor sites of organic Schiff base ligand based on 2hydroxynapthalene-1-carbaldehyde and their $\mathrm{Cu}$ (II) and $\mathrm{Co}$ (II) complexes,' International Journal of Advanced Scientific and Technical Research, vol. 5, no. 3, pp. 198-206, 2013.

[30] S. S. Swathy, R. Selwin Joseyphus, V. P. Nisha, N. Subhadrambika, and K. Mohanan, "Synthesis, spectroscopic investigation and antimicrobial activities of some transition metal complexes of a [(2-hydroxyacetophenone)-3-isatin]-bishydrazone," Arabian Journal of Chemistry, 2012.

[31] K. Siddappa and K. Mallikarjun, "Synthesis, characterization and antimicrobial studies of $\left(\mathrm{N}^{11} \mathrm{E}, \mathrm{N}^{\prime 6} \mathrm{E}\right)-\mathrm{N}^{\prime 1}, \mathrm{~N}^{\prime 6}$ bis ((6-bromo-2-hydroxyquinolin-3-yl)methylene) adipohydrazide," Archives of Applied Science Research, vol. 4, no. 3, pp. 1411-1417, 2012.

[32] J. Bjerrum, Metal Amine Formation in Aqueous Solution, P. Haase \& Sons, Copenhagen, Denmark, 1941.

[33] H. Irving and R. J. P. Williams, "The stability of transition-metal complexes," Journal of the Chemical Society, vol. 8, pp. 31923210, 1953.

[34] G. H. Olie and S. Olive, The Chemistry of the Catalyzes Hydrogenation of Carbon Monoxide, Springer, Berlin, Germany, 1984. 
[35] L. E. Orgel, An Introduction to Transition-Metal Chemistry: Ligand-Field Theory, Chapters 2-4, Methuen Publishing, 2nd edition, 1966.

[36] B. I. Omar, M. A. Mohamed, and M. S. Refat, "Nano sized Schiff base complexes with $\mathrm{Mn}$ (II), $\mathrm{Co}(\mathrm{II}), \mathrm{Cu}(\mathrm{II}), \mathrm{Ni}(\mathrm{II})$, Zn(II) metals: synthesis, spectroscopic and medicinal studies," Canadian Chemical Transitions, vol. 2, no. 2, pp. 108-121, 2014.

[37] M. Usharani, E. Akila, and R. Rajavel, "Dinuclear Cu(II), $\mathrm{Co}(\mathrm{II}), \mathrm{Ni}(\mathrm{II})$ and $\mathrm{Mn}$ (II) complexes framework based on 1(2-hydroxyphenyl) ethanone ligand: synthesis, structural investigation and biological properties," International Journal of Pharmaceutical Sciences Review and Research, vol. 21, no. 2, pp. 274-280, 2013.

[38] N. Dharmaraj, P. Viswanathamurthi, and K. Natarajan, "Ruthenium(II) complexes containing bidentate Schiff bases and their antifungal activity," Transition Metal Chemistry, vol. 26, no. 1-2, pp. 105-109, 2001.

[39] D. H. Petering, "Carcinostatic copper complexes," in Metal Ions in Biological Systems, H. Sigel, Ed., Marcel Dekker, New York, NY, USA, 1973.

[40] R. Gomathi and A. Ramu, "Synthesis, characterization of novel $\mathrm{Cu}$ (II) complexes of isatin derivatives as potential cytotoxicity, DNA binding, cleavage and antibacterial agents," International Journal of Innovative Research in Science, Engineering and Technology, vol. 2, no. 9, pp. 4852-4865, 2013.

[41] S. Subbaiyan, A. Ganesan, and J. B. Chinnasamy, "Synthesis, spectral, DNA binding and cleavage properties of ruthenium(II) Schiff base complexes containing PPh3/AsPh3 as coligands," Journal of the Serbian Chemical Society, vol. 79, no. 2, pp. 151-165, 2014. 

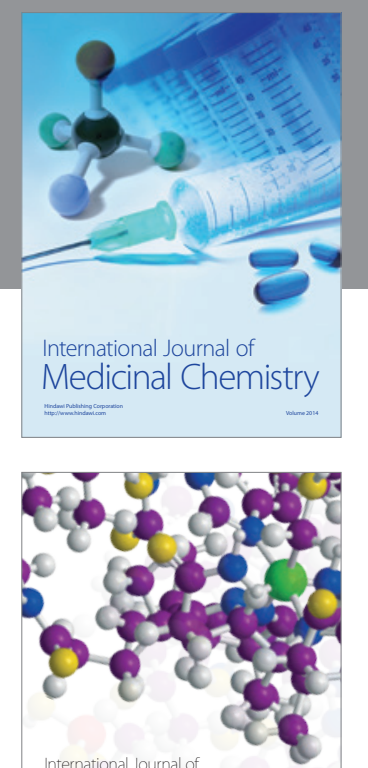

\section{Carbohydrate} Chemistry

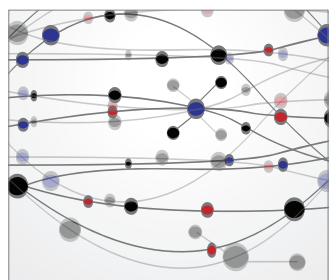

The Scientific World Journal
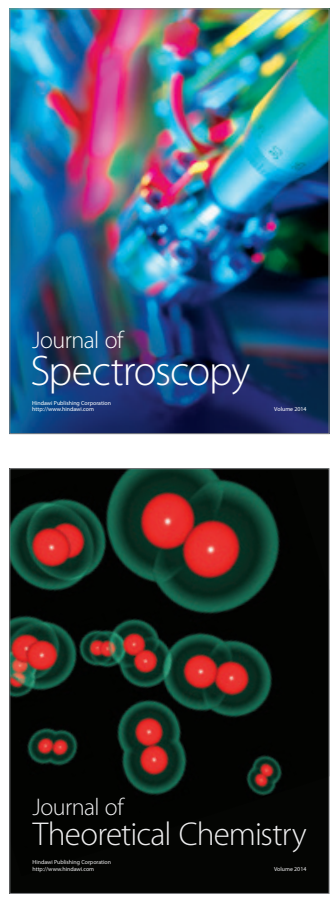
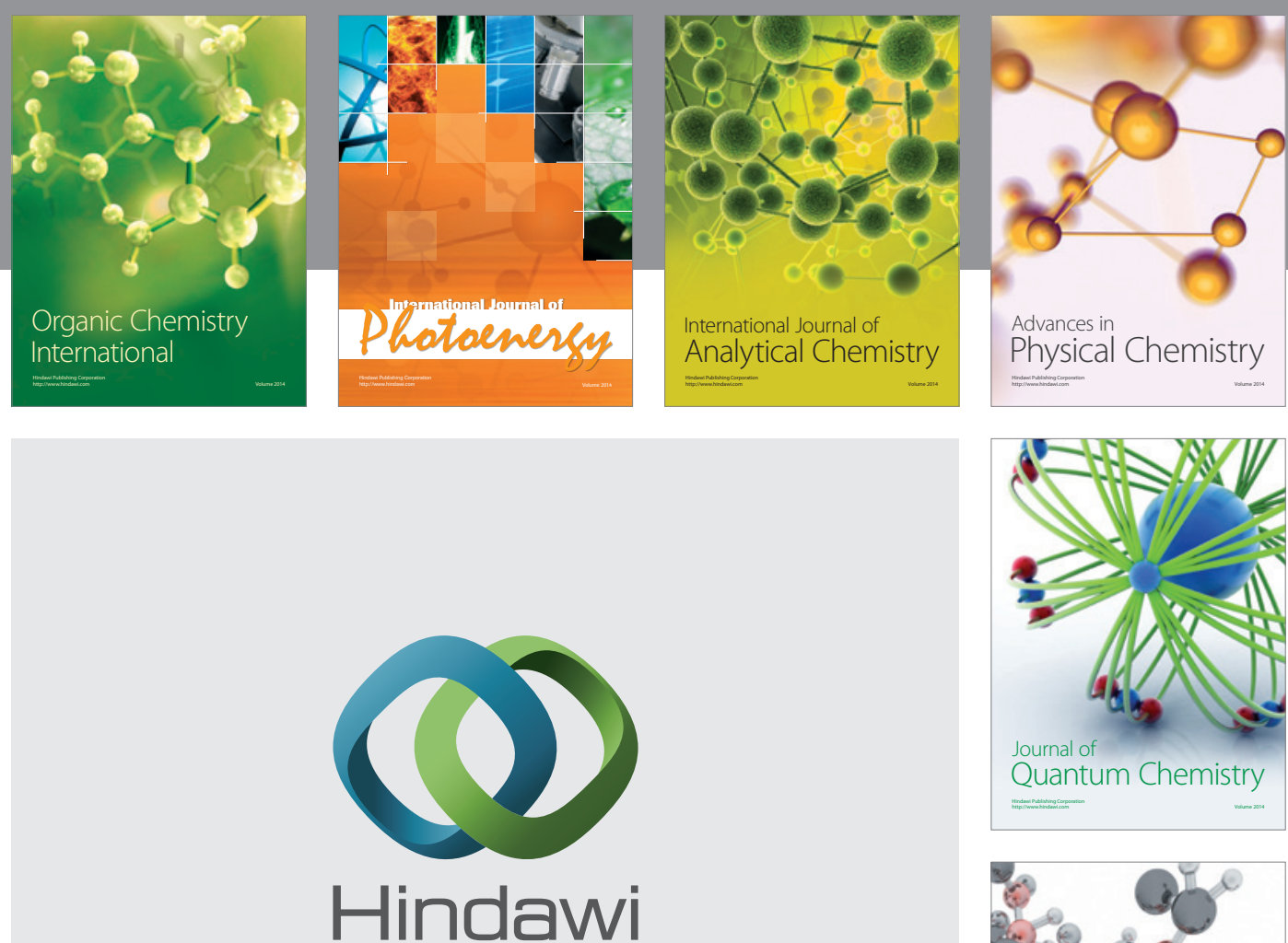

Submit your manuscripts at

http://www.hindawi.com

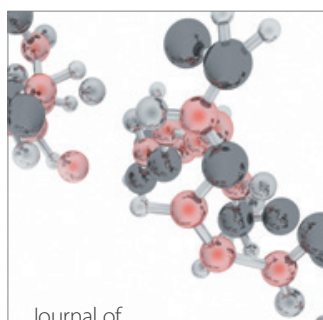

Analytical Methods

in Chemistry

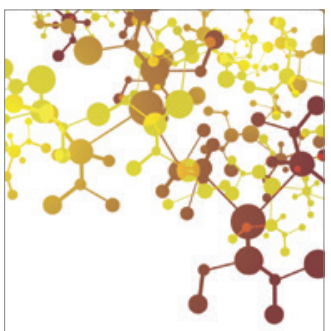

Journal of

Applied Chemistry

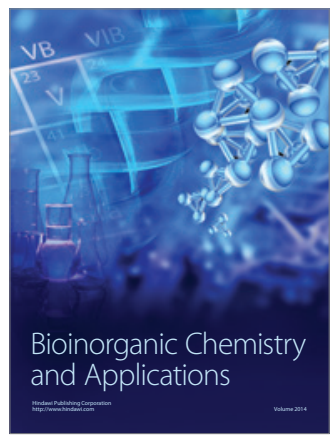

Inorganic Chemistry
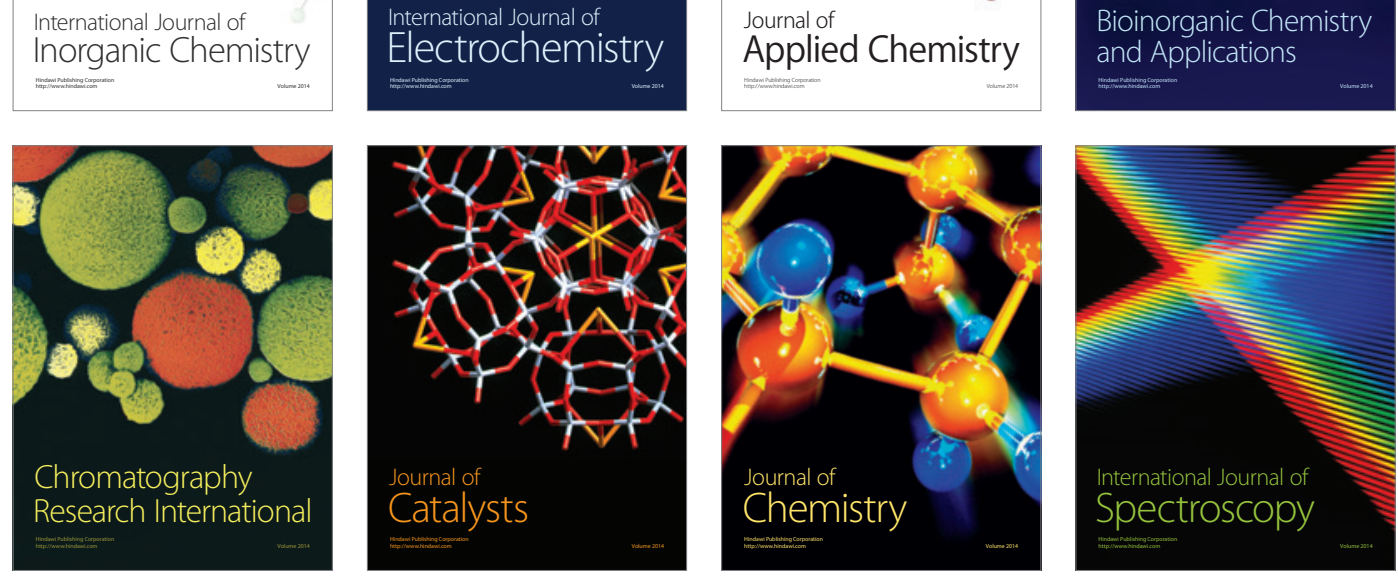